\title{
AGRICULTURE EXPORT STIMULANT TO THE ECONOMIC AND FINANCIAL PERFORMANCE OF PAKISTAN
}

\author{
Shaikh Muhammad Saleem ${ }^{1 *}$, Muhammad Asif Shamim², Sayma Zia ${ }^{3}$, Syed Waqar-ul-Hassan ${ }^{4}$ \\ ${ }^{1 *}$ Lecturer in Economics/Researcher, Pakistan Shipowners' Government College North Nazimabad, Block R \& S, \\ Karachi, Pakistan; ${ }^{2}$ Senior Assistant Professor, Management Studies Department, Bahria Business School, Bahria \\ University Karachi Campus, Karachi, Pakistan; ${ }^{3}$ Associate Professor, Principal/Head of the Department, Bahria Business \\ School, Bahria University Karachi Campus, Karachi, Pakistan; ${ }^{4}$ Director Quality Enhancement Cell, Salim Habib \\ University, Karachi, Pakistan. \\ Email: ${ }^{1 *}$ sheikhsaleem.m@gmail.com, ${ }^{2}$ asif_shamim19@ @otmail.com, ${ }^{3}$ samhha1@ hotmail.com, \\ ssyed.waqar@shu.edu.pk \\ Article History: Received on $9^{\text {th }}$ March 2021, Revised on 27 ${ }^{\text {th }}$ April 2021, Published on $29^{\text {th }}$ April 2021
}

\begin{abstract}
Purpose: The study examines how agricultural exports boost the economic growth of Pakistan in the long run and suggest policy implications during 1995-2018 using time series data.

Methodology: Principal Component Analysis is used to construct an agricultural export index consisting of rice, raw cotton, fruits, and vegetables as variables. This quantitative study checked the structural stability of the model with cumulative-sum \& cumulative-sum of the square. Rolling window analysis highlights the long-run yearly effect of the coefficient of the model. The result of variance decomposition method proof bidirectional causality where robust result proof using Fully modified ordinary least square and Dynamic ordinary least square techniques. Unit root at first difference proof stationery whereas cointegration has a long-run relationship between agricultural export and economic growth.
\end{abstract}

Main Finding: The statistical estimation proofs the positive long-run association of agricultural exports with economic growth. Results explored a 26 percent increase in the economy of Pakistan by exporting agricultural goods.

Application of this Study: This study helps to develop the economies if they face problems of low agricultural productivity. The agricultural export is sensitive to domestic indicators, and domestic policy can promote agricultural export, and create new potential markets.

The originality of the Study: The study is suggested the agriculture techniques and their performance in developing economies.

Keywords: Agricultural Export, Economic Growth, Time Series Model, Policy Implications.

\section{INTRODUCTION}

Agriculture trade plays a significant role in sustainable economic growth and development. It is considerable for the provision of consumable goods. Similarly, agricultural trade fulfils consumption demand and provides a path to lead economic growth (Jordaan \& Eita, 2007). From a large perspective, agriculture production has been increased globally, not only for domestic consumption but also for demand in other countries. Exports are necessary for the country because it earns foreign exchange. This foreign exchange reserve finance to; capital goods, consumable goods, energy payments, technology transfer, and few others. Agriculture credit is the most significant factor for the business world because export intensity can increase labour productivity. The easy and cheapest form of credit for agricultural activities can boost agricultural production, which may ultimately lead to agricultural exports and further betterment for the development of the economy (Rehman et al. 2017). The disequilibrium in the balance of payment can manage via export-led policies and make the strategy to facilitate the exporters because exports reduce the trade deficit. The economists have established the relationship between trade openness and economic development in the short and long run.

In contrast, other several studies are available on trade openness Hye and Lau (2015), international market Reardon and Barrett (2000), and economic growth (Jordaan \& Eita, 2007). However, the causal relationship of agricultural exports and economic growth is debatable because the positive correlation of export and real income growth has been found in most countries (Svedberg, 1991). Most developing countries relied on the agricultural sector to raise their export, but after World- War II, export has been distrusted in developed countries. The distrust demonstrated that imports from the developing countries could not be sustained in the international market (for developed countries) because the developing countries can pick up the pace of their development. There is also a case to support this predisposition; the industrial production of developed countries also influences the exports of developing countries.

Another possibility of this theory, the postwar period is not exemplified by the exclusive demand as the indicator of trade performance of developing countries, but supply should be the defining factor. Nevertheless, the 1980s crisis, decline in prices of primary products, and shuffling down the world economy presented the same picture of export distrust again. The international market works as a whole, and a single supplier does not affect the prices of primary products unless they increased their export to many countries. It is less likely that the price elasticity of demand goes less 
than one for the primary product for a single country (Thomas \& Nash, 1991). So, the government can increase its export which will be absorbed in the international market without price change. Prices will only fluctuate if there change in the cost of the world market. This way, most non-oil developing countries look to increase their agricultural export to navigate towards industrialisation. New policies are needed to define and determine the factors associated with improving the exports of a country.

\section{Agricultural Exports Performance - An Overview}

The agriculture sector provides food, raw material, foreign exchange, job opportunities, and others (Kiani et al., 2018). Its backbone for Pakistan's economy because it contributes a remarkable share in foreign exchange by exporting goods, and it is also survival for farmers \& their families. This sector contributes about 23.4 percent to the economy, while major exports consist of wheat, rice, cotton, sugarcane, and minor crops are Jawar and Bajra (Usman, 2016). According to the Economic Survey of Pakistan, major crops contributing almost 5.4 percent to GDP, and minor crops are contributing about 11.6 percent. (Kiani et al. 2018). Look at the crops, rice, wheat, raw cotton, sugarcane, fruits are considered essential and primary agricultural products of Pakistan. The cotton product earns nearly 65 percent of foreign exchange, rice is a rich source and consumed in almost every country of the world. Rice is also the primary source to make a large percentage of foreign exchange. About $\$ 19.2$ billion of the export proceeds are from agro-based products such as rice, cotton, fruits, vegetable, fish, and meats are 28 percent of other intermediate products such as yarn, the fabric is 22 percent, and the remaining 50 percent from textile and leather products.

However, Pakistan's overall agricultural export performance since the 1990s has been problematic, but even certain crops are relatively good such as rice, fruits, raw cotton, and vegetables. In the mid-90s, agricultural export declining trend up to the year 2002, one of the reasons behind declining is too focused on non-agricultural exports such as industrial products. Next five years up to 2007, performance has marginally increased. During 2007 to 2015 , drastic change emerges, where the performance of agricultural export proved good due to maintained international standards, enhanced per hector crops, and fulfill national and international consumer demand. Despite the downward trend from 2015, this sector still has a leading role in Pakistan's economy because of foreign earning, consumption needs, demographic influence, industrial requirement, and millions of labour force are employed. This study considering the performance of agricultural exports (products) and investigation, will provide ways to develop the possible solution to lift the economy by increasing agricultural exports.

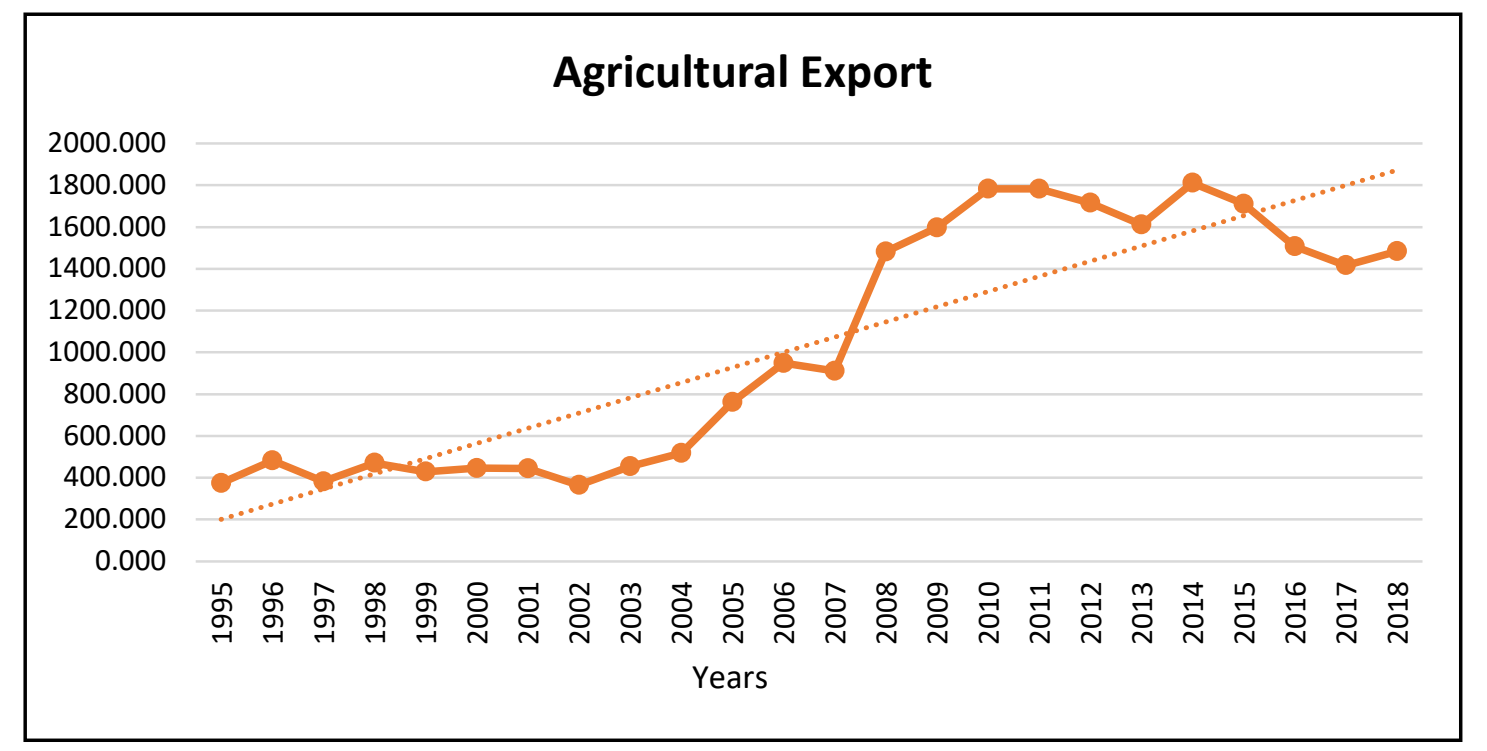

Figure 1: Trend in Agricultural Export

Source: Author estimation

\section{Construction of Agricultural Export - Index}

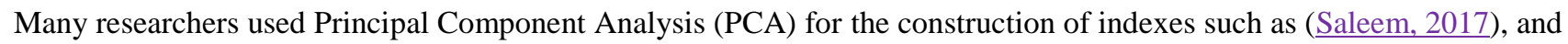
(Hye \& Lau, 2015). Its multivariate method ensures relation among quantitative variables and effectively extracts common measures from a set of liner variables. We used PCA to construct agricultural export index consisting of Rice, Raw-cotton, Fruits, and vegetables as variables. Even several built-in indexes or proxies are available in past literature, but we made a composite agricultural export index to check the concreate relationship with the economic growth of Pakistan. Eigenvalues in table 1 represents $79.78 \%, 15.44 \%, 3.68 \%$ and $1.10 \%$ proportion respectively. First Principal Component (PC-1) from eigenvectors (loadings), explain separate contribution of Rice (48.75\%), Raw-cotton (41.28\%), Fruits $(54.55 \%)$ and Vegetable $(54.25 \%)$ in agricultural exports (AGX) Index. 
Table 1: Results of Principal Component Analysis

\begin{tabular}{llllll}
\hline \multicolumn{7}{l}{ Eigenvalues: (Sum $=4$, Average $=1)$} \\
\hline PCA & Value & Difference & Proportion & Cumulative Value & Cumulative Proportion \\
\hline 1 & 3.1912 & 2.5736 & 0.7978 & 3.1912 & 0.7978 \\
\hline 2 & 0.6175 & 0.4702 & 0.1544 & 3.8088 & 0.9522 \\
\hline 3 & 0.1473 & 0.1034 & 0.0368 & 3.9561 & 0.9890 \\
\hline 4 & 0.0438 & ---- & 0.0110 & 4.0000 & 1.0000 \\
\hline Eigenvectors & (loadings) & & & & \\
\hline Variables & PC 1 & PC 2 & PC 3 & PC 4 & \\
\hline RICE & 0.4875 & -0.5243 & 0.6971 & 0.0375 & \\
\hline COTTON & 0.4128 & 0.8428 & 0.3433 & 0.0351 & \\
\hline FRUIT & 0.5455 & -0.0744 & -0.3979 & -0.7338 & \\
\hline VEGETABLE & 0.5425 & -0.0953 & -0.4876 & 0.6773 & \\
\hline Ordinary Correlation & & & & \\
\hline \multicolumn{7}{r}{} & RICE & COTTON & FRUIT & VEGETABLE & \\
\hline RICE & 1.0000 & ----- & ----- & ----- & \\
\hline COTTON & 0.4046 & 1.0000 & ---- & ---- & \\
\hline FRUIT & 0.8307 & 0.6586 & 1.0000 & ---- & \\
\hline VEGETABLE & 0.8259 & 0.6414 & 0.9555 & 1.0000 & \\
\hline
\end{tabular}

Source: Author construction

The focus of the study is to evaluate the role of agricultural exports in the economic growth of Pakistan. The following section covers the framework for investigating the performance of agricultural export and the economic growth of Pakistan.

\section{MATERIAL AND METHODS}

The section describes the model framework and statistical techniques consisting of time-series data from 1995 to 2018. Data are collected from the Handbook of statistics (State Bank of Pakistan), the Economic Survey of Pakistan (Ministry of finance), and the Pakistan statistical yearbook. The general equation describes as follow:

$$
R G D P=f(A G X, I N F, P O P, I F S)
$$

The above model covered, RGDP is a real gross domestic product used as market price. AGX is agricultural export used as an index (Index consists of Rice, Raw-cotton, Fruits, and Vegetable). INF is inflation used as price indices. POP is population used as urbanization, and IFS is the infrastructure used as total roads in kilometers.

$$
\operatorname{Ln}(Y)=\alpha+\beta \operatorname{Ln}(A G X)+\gamma_{\operatorname{Ln}(X)}+\mu
$$

The above equation parameter is developed as a model. In contrast, $\mathrm{Y}$ is used as the dependent variable, AGX is used as an independent variable, $\mathrm{X}$ is used as a control variable, $\mathrm{Ln}$ is used as $\log , \mu$ is used as an error term.

\section{ANALYSIS OF RESULTS}

\section{Unit Root test}

All variables have non-stationary at the level and become stationary at the first difference by using Augmented Dickey and Fuller (1979, ADF), and Phillips and Perron (1988, PP) reported in table 2. According to the result, real Gdp, agriculture exports, and all control variables are stationary at $I(1)$, which means variables are integrated in one order.

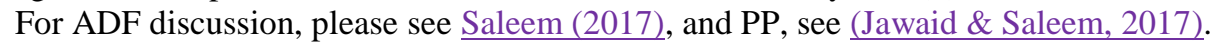

Table 2: Results of Unit Root Test

\begin{tabular}{lcccccccc}
\hline & \multicolumn{4}{c}{ ADF statistics } & \multicolumn{4}{c}{ PP statistics } \\
\hline & \multicolumn{3}{c}{ Level } & \multicolumn{1}{c}{$1^{\text {st }}$ difference } & \multicolumn{2}{c}{ Level } & \multicolumn{1}{c}{$1^{\text {st }}$ difference } \\
\hline Variables & C & C \& T & C & C \& T & C & C \& T & C & C \& T \\
\hline LGDP & -1.06 & -0.92 & -4.25 & -4.35 & -1.06 & -1.03 & -4.25 & -4.35 \\
\hline LAGX & -1.05 & -1.13 & -5.04 & -4.92 & -1.07 & -1.32 & -5.02 & -4.92 \\
\hline LINF & -1.58 & -1.57 & -4.67 & -4.67 & -1.66 & -1.63 & -4.67 & -4.68 \\
\hline LPOP & -0.86 & -1.63 & -4.87 & -5.03 & 1.01 & -1.63 & -4.87 & -5.03 \\
\hline LIFS & -1.92 & 2.14 & -3.71 & -4.10 & -1.09 & -1.40 & -3.75 & -4.09 \\
\hline
\end{tabular}

Source: Author's estimation

Note: Critical values of ADF and PP for Intercept (C) are $-3.75,-2.99,-2.63$ and whereas Trend \& Intercept (C \& T) are $-4.41,-3.62,-3.24$ at $1 \%, 5 \%, 10 \%$ level of significance respectively. 


\section{Johansen and Juselius (JJ) cointegration}

Table 3 represents the Johansen and Juselius (1990) result of cointegration with Trace values and Maximum Eigenvalues. According to JJ statistics, the null hypothesis of no cointegration is rejected because values in trace statistics are more significant (greater) than the critical value at the level of 5\%. Therefore, it is confirmed that a long-run association exists among dependent and independent variables in the model.

Table 3: Results of JJ cointegration

\begin{tabular}{ccccc}
\hline Hypothesis & Trace Statistics & $\mathbf{5 \%}$ Criticalvalues & Max.Eigen Values & 5\% CriticalValues \\
\hline No. of CE (s) & (Calculated Values) & (Table Values) & (Calculated Values) & (Table values) \\
\hline None & 156.38 & 88.8 & 66.34 & 38.33 \\
\hline At most 1 & 90.03 & 63.87 & 30.91 & 32.11 \\
\hline At most 2 & 59.11 & 42.91 & 27.22 & 25.82 \\
\hline At most 3 & 31.89 & 25.87 & 23.27 & 19.38 \\
\hline
\end{tabular}

Source: Author's estimation

\section{Residual-based cointegration}

The test of Engle and Granger (1987) in table 4 proved a long-run relationship between agricultural exports and economic growth of Pakistan by using ADF and PP statistics; for detail, see (Saleem, 2017).

Table 4: Results of Engle and Granger cointegration

\begin{tabular}{ccc}
\hline Test & Constant & Constant \& Trend \\
\hline ADF & -3.88 & -3.69 \\
\hline PP & -2.95 & -2.73 \\
\hline
\end{tabular}

Source: Author's estimation

Note: Critical values of ADF and PP for Intercept $(C)$ are $-3.95,-3.08,-2.68$ whereas Trend \& Intercept $(C \& T)$ are $4.72,-3.75,-3.32$ at $1 \%, 5 \%, 10 \%$ level of significance respectively.

\section{Long Run Regression}

In the following table 5, the long-run relationship between agriculture exports and economic growth found a significant positive effect and consisting with (Kiani et al., 2018). This model also found a significant positive effect of inflation and population in the long run, whereas infrastructure shows an insignificant positive impact on economic growth. Initial regression applied the HAC option to correct autocorrelation and heteroscedasticity issues.

Table 5: Results of Ordinary Least Square

\begin{tabular}{lccc}
\hline Variables & Coefficient & T-Stats & Prob. \\
\hline C & -13.32 & -3.54 & 0.002 \\
\hline LAGX & 0.26 & 3.12 & 0.005 \\
\hline LINF & 0.08 & 1.75 & 0.096 \\
\hline LPOP & 5.12 & 9.61 & 0.000 \\
\hline LIFS & 0.08 & 0.17 & 0.860 \\
\hline Adj. ${ }^{2}$ & & 0.995 & \\
\hline F-stats (Prob.) & & 0.000 & \\
\hline Durbin Watson stat & & 1.414 \\
\hline
\end{tabular}

Source: Author estimation

\section{Stability Test}

Monk and Brown (1975) introduced cumulative-sum (CUSUM) and cumulative sum of square (CUSUMQ) statistics to check the structural stability of the model. CUSUM is used to checks the instability of the coefficient, but no instability is found in the model (figure 2). Whereas the CUSUMQ test detects the random instability of coefficient in 2007 (figure 3).

\section{Chow Breakpoint}

Chow (1960) the test is used to find breakpoint year in time series data. Results of CUSUMQ reported in figure 3, found a breakpoint in 2007 because table 6 proved the significant value of Chi-Square. 


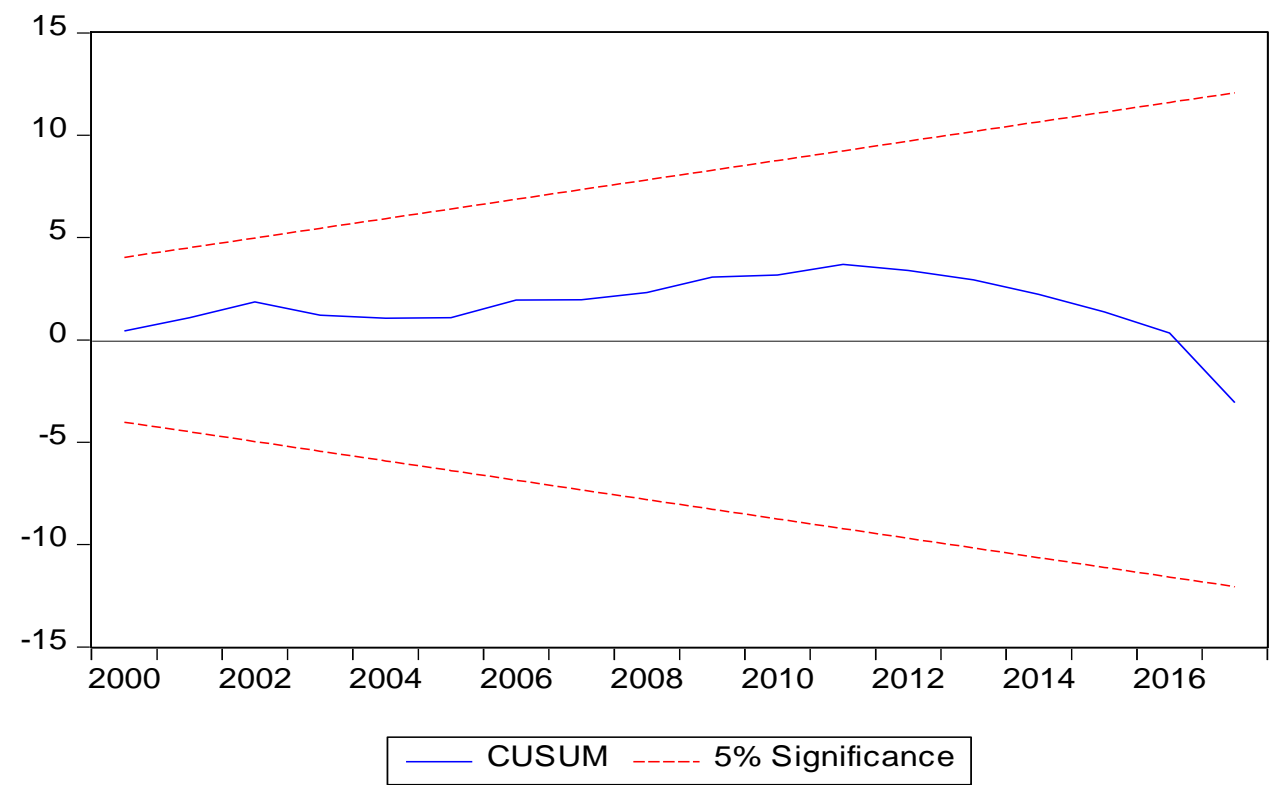

Figure 2: Cumulative-Sum

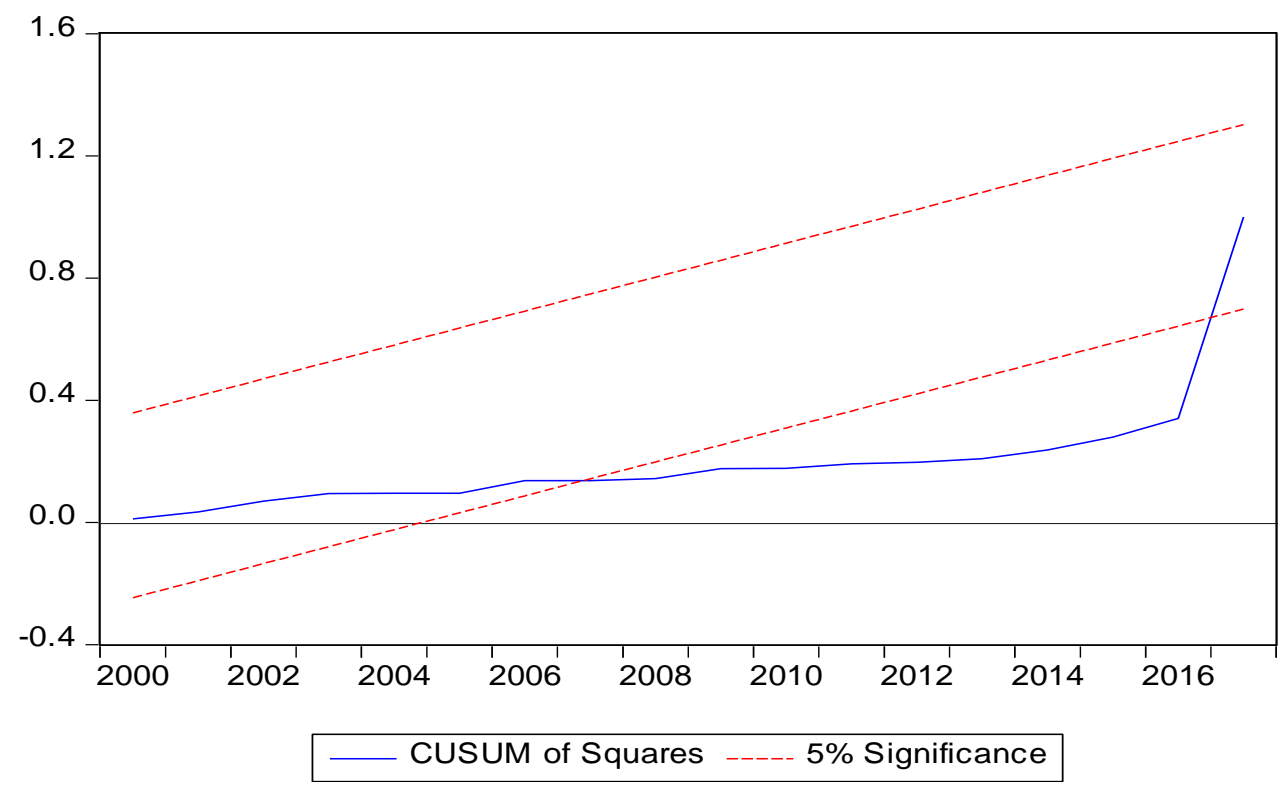

Figure 3: Cumulative-Sum of Square

Table 6: Result of Chow Breakpoint

\begin{tabular}{lcc}
\hline F-statistic (Prob.) & Prob. F & Chi-Square \\
\hline 7.768 & 0.001 & 0.000 \\
\hline
\end{tabular}

Source: Author's estimation

Note: Breakpoint year 2007

\section{Rolling window}

The strength of coefficients of the model through the sample size is analyzed here by applying rolling window analysis. This analysis facilitates the research process that shows the behaviour of coefficients as crystal clear through the sample period (Jawaid \& Saleem, 2017).

Table 7: Rolling Window: Long-run coefficients of AGX

\begin{tabular}{cccc}
\hline Years & Coefficients & Years & Coefficients \\
\hline 2002 & 0.0983 & 2011 & 0.20533 \\
\hline 2003 & -0.0535 & 2012 & 0.40164 \\
\hline 2004 & -0.02376 & 2013 & 0.25248 \\
\hline
\end{tabular}




\begin{tabular}{cccc}
\hline 2005 & -0.01272 & 2014 & 0.21778 \\
\hline 2006 & -0.08432 & 2015 & 0.05824 \\
\hline 2007 & 0.03189 & 2016 & 0.00631 \\
\hline 2008 & 0.06968 & 2017 & -0.09578 \\
\hline 2009 & 0.13892 & 2018 & 0.04472 \\
\hline 2010 & 0.13254 & & \\
\hline
\end{tabular}

Source: Author's Estimation

Table 7 reflects the coefficient of agriculture exports and economic growth concerning the positive and negative impact. The coefficient of AGX shows higher values, and it has positive results from the 2007 to 2016 period, whereas from the year 2003 to 2006 and again 2017 shows negative values about agricultural performance-graphical representation of the coefficient estimated in figure 4. The blue line represents the coefficient of AGX, whereas the upper and lower lines indicate standard deviation. Although the coefficient depicted mixed behaviour, at the same time, it remained positive almost throughout the sample period.

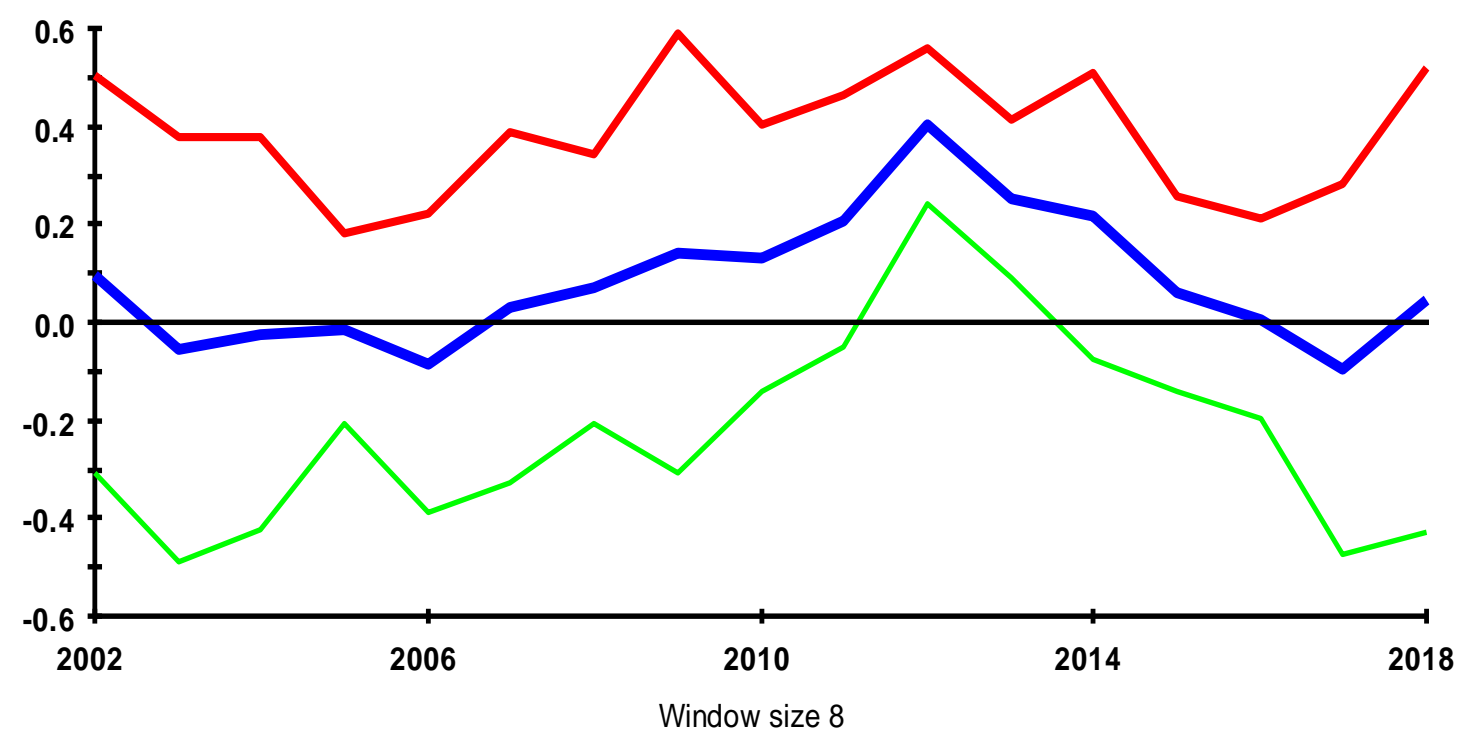

Figure 4: Rolling Window

Source: Author's Construction

Note: Coefficient of AGX and its two SE bands based on rolling OLS (Dependent variable: GDP)

\section{FMOLS and DOLS Sensitivity Test}

Fully Modified Ordinary Least Square (FMOLS) was introduced by (Phillips \& Hansen, 1990), whereas Dynamic Ordinary Least Square (DOLS) was introduced by Stock and Watson (1993) to check the robustness of the initial model. FMOLS removes serial correlation and endogeneity issues from the regressor, whereas DOLS augment the cointegrating regression with one lead and lag value with the fixed method. The following table 8 proved a long-run relationship between agriculture export and economic growth, the same as the initial result.

Table 8: Results of FMOLS and DOLS statistics

\begin{tabular}{lcccc}
\hline & \multicolumn{2}{c}{ FMOLS } & \multicolumn{2}{c}{ DOLS } \\
\hline Variables & Coefficients & Prob. & Coefficients & Prob. \\
\hline LAGX & 0.27 & 0.000 & 0.23 & 0.000 \\
\hline LINF & 0.08 & 0.002 & 0.08 & 0.026 \\
\hline LPOP & 5.08 & 0.000 & 4.92 & 0.000 \\
\hline LIFS & 0.13 & 0.604 & 1.30 & 0.104 \\
\hline
\end{tabular}

Source: Author's Estimation

Note: Pooled weighted DOLS with 1 lead and lag

\section{VDM Causality test}

Variance Decomposition Method (VDM) was developed by Pesaran and Shin (1998) to examine the variation in 
variables of the model. In table 9, the first and tenth periods indicating $100 \%$ and $2.44 \%$ variation in GDP on their own whereas, $9.15 \%$ and $38.97 \%$ variation in GDP by AGX at fifth and tenth periods respectively that proved, variation in GDP not influenced by agricultural exports. Similarly, variation in AGX on its own at first and tenth periods as $99.61 \%$ and $41.64 \%$, respectively. In contrast, GDP explains $27.85 \%$ and $3.97 \%$ of the variation in AGX at the fifth and tenth periods, which proved a bidirectional causal relationship exists between agriculture export and economic growth.

Table 9: Results of Variance Decomposition Method

\begin{tabular}{|c|c|c|c|c|c|}
\hline Period & GDP & AGX & AGX & POP & IFS \\
\hline \multicolumn{6}{|c|}{ Variance decomposition of GDP } \\
\hline 1 & 100.0000 & 0.000000 & 0.000000 & 0.000000 & 0.000000 \\
\hline 2 & 66.62224 & 12.82386 & 3.857774 & 10.76254 & 5.933586 \\
\hline 3 & 56.80438 & 22.32679 & 3.507055 & 12.71019 & 4.651580 \\
\hline 4 & 38.99176 & 15.65312 & 2.665573 & 39.48675 & 3.202792 \\
\hline 5 & 44.01494 & 9.150333 & 1.570984 & 43.42408 & 1.839653 \\
\hline 6 & 26.49486 & 13.46669 & 0.655444 & 58.59571 & 0.787296 \\
\hline 7 & 20.20749 & 22.79380 & 3.822584 & 52.33152 & 0.844600 \\
\hline 8 & 9.301213 & 33.09035 & 7.118334 & 49.71029 & 0.779808 \\
\hline 9 & 5.329140 & 37.30967 & 14.63127 & 41.15359 & 1.576326 \\
\hline 10 & 2.443470 & 38.97713 & 18.44784 & 38.37306 & 1.758499 \\
\hline \multicolumn{6}{|c|}{ Variance decomposition of AGX } \\
\hline 1 & 0.384006 & 99.61599 & 0.000000 & 0.000000 & 0.000000 \\
\hline 2 & 18.14638 & 78.75481 & 1.980379 & 0.000151 & 1.118285 \\
\hline 3 & 21.38796 & 50.41105 & 15.15404 & 10.75305 & 2.293901 \\
\hline 4 & 34.62453 & 39.11545 & 15.88572 & 8.583477 & 1.790824 \\
\hline 5 & 27.85603 & 29.24583 & 16.31044 & 24.81063 & 1.777074 \\
\hline 6 & 30.98661 & 29.95547 & 13.58663 & 23.90673 & 1.564562 \\
\hline 7 & 17.91471 & 38.53099 & 8.282895 & 34.36897 & 0.902439 \\
\hline 8 & 12.65711 & 42.92756 & 14.12369 & 28.49108 & 1.800558 \\
\hline 9 & 6.690783 & 44.55519 & 15.85876 & 31.41890 & 1.476363 \\
\hline 10 & 3.974440 & 41.64613 & 25.96212 & 25.69993 & 2.717372 \\
\hline
\end{tabular}

Source: Author's estimation

\section{POLICY DISCUSSION}

Although the results are significant but suggest that agricultural export is sensitive to domestic indicators and needs economic reform. The government should design a domestic policy to improve supply that aimed to promote agricultural export; for this need to analyze new potential markets. Generally, agricultural development is a way to reduce rural poverty, wealth creation, food availability, edge comparative advantage, political recognition, and make an excellent international affair. Whereas, in Pakistan agriculture sector became a victim of policy discrimination after promoting industrialization in the 90s. Pakistan has agricultural dependence but importing few consumer goods due to comparative advantage that is one reason for declining agricultural export. Similarly, below standardization adversely affects export supply, for this government initiative to use (abundance) natural resources combined with low labour costs. With the pressure of the world market, the government must produce their product with a comparative advantage by achieving low transportation and transaction costs.

Even the foreign income increased market size and creates more agricultural demand over the price stability, but it can reduce agricultural export due to domestic demand. Therefore, the export promotion should aim at market diversification in those countries where farmers are exploited for their comparative advantage. On the other hand, more attention is required to achieve the competitiveness of domestic farmers because the major population lived and associated with the agriculture sector. The lack of rural infrastructure like roads increases transportation costs that demotivates small farmers, whereas good infrastructure to have market access. So that the farmers may have the potential to become a competitive factor in international markets. Pakistan is greatly dependent upon the agriculture sector; it serves as the country's backbone and contributes a significant share in its economic growth. A greater part of Pakistan's population is subject to this area, and it contributes around 24 percent of GDP (Pakistan Bureau of Statistics, 2021). However, this backbone is not given adequate support and is required to maintain stability. The agriculture sector of Pakistan has faced a turmoil of complications and difficulties over the years. Some of the major drawbacks that hinder the process of a flourished agriculture with reforms are discussed below: 
Pakistan has a total of 79.6 million hectares of land Dawn (2021); FAO (2021) that could be cultivated and made fertile for higher yield, but only 22.1 of the land is used for cultivation. The abundance of land needs to be catered to by making land reforms and non-fragmented lands to the cultivating community. The remaining 57.5 percent of the land can be provided to the land-less farmers and taken into use for maximizing yield and generating higher economic output. The history of land reforms in Pakistan has not-so-pleasant, whereas the significant changes came in three phases: the first during Ayub Khan's military law in 1959; the second and third during Zulfiqar Ali Bhutto's standard during the 1970s. In any case, these land reforms were consistently dubious and did not meet the necessities set forward. Since then, the government did not make proper land reforms. Even though Pakistan was always in desperate need of good land reforms. Considering China's operation model, they have such land reforms that ensure maximum efficiency, excellent yield and production, and guaranteed growth movement. Pakistan's policymakers should keep such examples in mind while working on their own. On the other side, the government should make strategies and keep the costs of different food crops reasonable for the helpless masses, likewise guaranteeing productivity for the cultivators. There is additionally a need to give incentives to the cultivators to eradicate the inadequate supply of agriculture inputs, for example, quality seeds (have a significant effect on the growth) and arrangement of loans, for the acquisition of work vehicles and other equipment required for progressive cultivating techniques. Various responses suggest that farmers are unable to work efficiently because the vehicles provided to them are inadequate. In recent years, Pakistan is importing agricultural equipment, especially from China, because China operates on high-quality equipment, which provides a higher efficiency ratio. If such valuable imports are made, they can bring a revolution into the agricultural sector. Composts and fertilizers are the principal inputs used to accomplish high and quick rates of agricultural return. For example, 1 kilogram of supplement manure produces around 8 kilograms of healthy grain. The essential manners by which farming efficiency can be improved by using better seeds, proper use of fertilizer, pesticides, and the utilization of present-day agricultural innovation. Appropriate fertilization treatment can improve harvest yields and rural income.

Another serious issue is water availability and lack of irrigation facilities. The canal system of Pakistan facilitates around 70-80 percent of the area for irrigation purposes, out of which 30 percent absorbed into the ground due to inadequate drainage before it could reach into the agricultural fields (irrigation). However, these issues can fix if government pays a little more attention to the construction of dams. If the hydroelectric Kala-Bagh dam in the Mianwali district Punjab, constructed, then can resolve various water crises and flooding issues. Flood is another crisis under the fall of agricultural production that is also the reason for less export. It is suggested that the Kala Bagh dam can generate a revenue of $\$ 3$ billion and 4000 megawatts of electricity production per annum, Abbas (2015). It would be a massive step towards eradicating power issues in Pakistan, that will reduce the power crisis and irrigation malfunction. Agricultural production will double due to this marvellous creation as 400000-acre feet of supplementary water will be available in Sindh, 220000 in Punjab, 200000 in KPK, and 150000 in Balochistan will be available for agriculture production. After the resolution of the water crisis will give rise to the great production of essential crops like jute, rice, vegetables, fruits, and sugarcane. Similarly, the construction of the hydroelectric DASU dam will produce 4320 megawatts of electricity which will reduce the cost of electricity in Pakistan and maximize the rate of agricultural production to great extents, Zaidi (2015).

Inadequate agricultural research centres are another drawback. Therefore, it needs to promote and established technical and vocational education in Pakistan. Even few technical and vocational education institutions are available, but it needs to joint venture with industries for technical assistance. If proper checks and balances are maintained through monitoring, adequate facilitation, and output audit, Pakistan can touch heights of production and prosperity. The cultivating local community has great hopes with the financial administrators taking more substantial measures to give long-term help to maximise yields. If the measures mentioned above, are taken into account while developing counterstrategies, Pakistan can eradicate the agricultural crisis and proceed towards prosperity.

\section{CONCLUSION}

The statistical estimation proves a positive long-run relationship between agricultural exports and the economic growth of Pakistan during 1995-2018 with time-series data. Results indicating a 26 percent increase in the economy of Pakistan by exporting agricultural goods. Similarly, control variables such as inflation and population have a significant positive impact, whereas infrastructure has an insignificant positive effect on economic growth. Cointegration has a long-run relationship, whereas structural changing check by cumulative-sum and cumulative sum of the square found stability in coefficient except 2007 in the cumulative sum of the square. Rolling window analysis highlights the overall positive long-run yearly effect of the coefficient of the model. The bidirectional causality found with variance decomposition method and initial result is robust with fully modified ordinary least square \& dynamic ordinary least square methods.

\section{LIMITATIONS AND STUDY FORWARD}

There is still scope in this research related to the same economy segment with individual or group of countries. The nonavailability of the large size of the data may be an issue.

\section{STATEMENT OF DISCLOSURE}

We have no conflict of interest, financial or otherwise. 


\section{CO-AUTHORS CONTRIBUTIONS}

The second co-author made the part of rolling window analysis, write-up policy discussion, and suggested a title of the paper. The third and fourth co-authors review the article

\section{REFERENCES}

1. Abbas, M. N. (2015). Energy crisis in Pakistan Naval Postgraduate School Monterey United States. The USA. https://apps.dtic.mil/sti/pdfs/AD1009049.pdf

2. Akbar Zaidi, S. (2015). Issues in Pakistan's economy: a political economy perspective. Oxford University Press Catalogue.

3. Chow, G. C. (1960). Tests of equality between sets of coefficients in two linear regressions. Econometrica: Journal of the Econometric Society, 28(3), 591-605. https://doi.org/10.2307/1910133

4. Dawn. (2021). Sustainable agriculture in rain-fed areas. DAWN. Retrieved Aug/2021 from https://www.dawn.com/news/257612/sustainable-\%20agriculture-in-rain-fed-areas

5. Dickey, D., \& Fuller, W. A. (1979). Distribution of the estimators for time series regressions with a unit root. Journal of the American Statistical Association, 74(366), 427-431. https://doi.org/10.2307/2286348

6. Engle, R. F., \& Granger, C. W. (1987). Co-integration and error correction: representation, estimation, and testing. Econometrica: Journal of the Econometric Society, 55(2), 251-276. https://doi.org/10.2307/1913236

7. FAO. (2021). Pakistan at a Glance. Food and Agriculture Organization of the United States. Retrieved Aug 2021 from http://www.fao.org/pakistan/our-office/pakistan-at-a-glance/en/

8. Hye, Q. M. A., \& Lau, W.-Y. (2015). Trade openness and economic growth: empirical evidence from India. Journal of Business Economics and Management, 16(1), 188-205. https://doi.org/10.3846/16111699.2 012.720587

9. Jawaid, S. T., \& Saleem, S. M. (2017). Foreign capital inflows and economic growth of Pakistan. Journal of Transnational Management, 22(2), 121-149. https://doi.org/10.1080/15475778.2017.1302784

10. Johansen, S., \& Juselius, K. (1990). Maximum likelihood estimation and inference on cointegration-with applications to the demand for money. Oxford Bulletin of Economics and Statistics, 52(2), 169-210. https://doi.org/10.1111/j.1468-0084.1990.mp52002003.x

11. Jordaan, A. C., \& Eita, J. H. (2007). Export and economic growth in Namibia: a Granger causality analysis. South African Journal of Economics, 75(3), 540-547. https://doi.org/10.1111/j.1813-6982.2007.00132.x

12. Kiani, A., Ijaz, F., \& Siddique, H. M. A. (2018). Determinants of Agricultural Exports of Pakistan: An Application of Gravity Model. Dialogue (Pakistan), 13(4), 467-478.

13. Monk, T. H., \& Brown, B. (1975). The effect of target surround density on visual search performance. Human Factors, 17(4), 356-360. https://doi.org/10.1177/001872087501700406

14. Pakistan Bureau of Statistics. (2021). Agriculture Statistics. Pakistan Bureau of Statistics, Government of Pakistan. Retrieved Aug/2021 from https://www.pbs.gov.pk/content/agriculture-statistics

15. Pesaran, H. H., \& Shin, Y. (1998). Generalized impulse response analysis in linear multivariate models. Economics Letters, 58(1), 17-29. https://doi.org/10.1016/S0165-1765(97)00214-0

16. Phillips, P. C., \& Hansen, B. E. (1990). Statistical inference in instrumental variables regression with I (1) processes. The Review of Economic Studies, 57(1), 99-125. https://doi.org/10.2307/2297545

17. Phillips, P. C., \& Perron, P. (1988). Testing for a unit root in time series regression. Biometrika, 75(2), 335-346. https://doi.org/10.2307/2336182

18. Reardon, T., \& Barrett, C. B. (2000). Agroindustrialization, globalization, and international development: An overview of issues, patterns, and determinants. Agricultural economics, 23(3), 195-205. https://doi.org/10.1016/S0169-5150(00)00092-X

19. Rehman, A., Chandio, A. A., Hussain, I., \& Jingdong, L. (2017). Is credit the devil in agriculture? The role of credit in Pakistan's agricultural sector. The Journal of Finance and Data Science, 3(1-4), 38-44. https://doi.org/10.1016/j.jfds.2017.07.001

20. Saleem, S. M. (2017). does international financial integration spur economic growth? Evidence from Pakistan. Journal of Management Sciences, 4(1), 116-130. https://doi.org/10.20547/jms.2014.1704107

21. Stock, J. H., \& Watson, M. W. (1993). A simple estimator of cointegrating vectors in higher order integrated systems. Econometrica: Journal of the Econometric Society, 61(4), 783-820. https://doi.org/10.2307/2951763

22. Svedberg, P. (1991). The export performance of sub-Saharan Africa. Economic Development and Cultural Change, 39(3), 549-566. https://doi.org/10.1086/451890

23. Thomas, V., \& Nash, J. (1991). Reform of trade policy: recent evidence from theory and practice. The World Bank Research Observer, 6(2), 219-240. https://doi.org/10.1093/wbro/6.2.219

24. Usman, M. (2016). Contribution of agriculture sector in the GDP growth rate of Pakistan. Journal of Global Economics, 4(2), 1-3. https://doi.org/10.4172/2375-4389.1000184 